\title{
Effect of Transient Treatment with Propylthiouracil on Some Reproduction Traits and Live Weight of Japanese Quails
}

-Author(s)
Sogut $B^{\prime}$
Sengul $T^{\prime}$
Inci $H^{\prime}$
Sengul Y'
Ayasan T"
। Department of Animal Science, Faculty of
Agriculture, Bingol University, Turkey
" Eastern Mediterranean Agricultural Re-
search Institute, Adana, Turkey

\section{Mail Address}

Corresponding author e-mail address Dr. Bunyamin Sogut

Department of Animal Science, Faculty of Agriculture, Bingol University, 12000, Bingol/TURKEY

Tel: $\quad$ +904262160030/1141

Email: bunyaminsogut@hotmail.com

\section{neywords}

Quail, propylthiouracil, live weight, reproduction traits.

\section{ABSTRACT}

This study was conducted to investigate the effects of transient treatment with propylthiouracil (PTU) on some reproduction traits and live weight of quails. The trial lasted 8 weeks. To accomplish this goal, 7001 -day-old quail chicks were used, randomly divided into 8 groups. PTU was added to feed by $0.1 \%$ and $0.5 \% / w t$. The first 4 groups had $0.5 \%$ PTU at the age of $2-4,4-6,6-8$ and $2-8$ wk., respectively. The $5^{\text {th }}$, $6^{\text {th }}$ and $7^{\text {th }}$ groups had $0.1 \%$ PTU at the age of $2-4,4-6$ and $6-8$ wk., respectively, and the $8^{\text {th }}$ group was the control with no PTU. Quails were bled at 60 days of age. Then right and left testes were taken out and weighed. At the end of the trail, least square means of the live weight of the treatment groups were higher than the control $(p<0.05)$. Similar results $(p<0.05)$ were observed for testis weight, testis diameter and fertility rate. As a result, it can be said that the inclusion of PTU in quail rations positively affects the live weight and reproduction traits of quails.

\section{INTRODUCTION}

There is no possibility to make a change on the genotype of a living thing after the zygote is formed. But it is possible to influence the nervous system and endocrine system that regulate metabolic events. In other words, it is possible to provide economic benefit by accelerating or slowing the role played by organisms by decreasing and multiplying the amount of hormones secreted by the endocrine system organs that regulate metabolic events (Ozkan \& Bulgurlu 1995). One of these organs is the thyroid gland.

Thyroid gland hormones have important effects on the reproductive mechanism. These hormones are effective by directly stimulating the metabolism of the sexual glands by stimulating and restricting the release of the anterior pituitary hormones, which control sexual function. The normal release of thyroid hormones is necessary for normal sexual function. The release of these hormones more or less causes different effects on the glands (Yilmaz, 1999). In some studies with temporary release of low levels of thyroid hormones, increased sperm production (Kirby \& Mankar, 1995) with the development and growth of testes (Cooke et al., 1991, Palmero et al., 1992; Kolaja et al., 2000) were observed. Among the most frequently used substances, methyl, propyl and isopropyl thiouracil can be considered to reduce the function of the thyroid gland. Unlike iodine proteins, these substances reduce metabolic activity by slowing the function of the thyroid gland (hypothyroidism) (Cooke et al., 1993; Kirby \& Mankar, 1995).

The main effect of PTU, which is used to slow down the function of the thyroid gland, is to decrease T3 and T4 in blood plasma concentrations, and to increase thyroid function by the thyroid follicle 
cells (Bunick et al., 1984). Similar effects are seen in domestic poultry such as chicken (Kai et al., 1993) and turkey (Queen et al., 1997).

The effects of transient PTU application in poultry on fertility, sexual maturity (Marks 1969), immunological system (Kai et al., 1993), testicular weight, volume and sperm production (Kirby \& Mankar, 1995, Kirby et al., 1996), developmental hormones (Tsukada et al., 1996) and molting period (Queen et al., 1997) were positive, however, on immunization system (Kai et al., 1993; Schmiedeberg et al., 1996) and ascites syndrome (Luger et al., 2002) were adverse.

These studies on poultry suggest that the application of PTU will affect the reproductive traits in quails. It is also a fact that the findings obtained with this study will contribute to artificial insemination practices in quails. The main objective of this study in the light of studies mentioned above was to figure out the effect of PTU added in the diet in different level on growth and testis traits of quail.

\section{MATERIAL AND METHODS}

This experiment was done at the Facility of Faculty of Agriculture, in Bingol University. In total 7001 day old Japanese quails were fed with $24 \%$ crude protein and $3100 \mathrm{kcal} / \mathrm{kg} \mathrm{ME} \mathrm{commercial} \mathrm{chick} \mathrm{diet} \mathrm{for} \mathrm{the} \mathrm{first}$ 14 days, without gender discrimination. After the 13 days of age, 480 male animals were subjected to PTU treatment by gender discrimination. The remaining 220 female animals were fed to investigate the effect of PTU administration on incubation performance.

PTU was added in the diet by 0.1 and $0.5 \%$ of the feed. Rations were fed to groups of 2-4, 4-6, 6-8 and 2-8 weeks, for two weeks in order to determine the age at which the PTU was more effective (1g PTU per $\mathrm{kg}$ feed). There were 3 replications in each group and 20 birds in each replicate. In the second treatment group, the dose effect ( $5 \mathrm{~g}$ PTU at $1 \mathrm{~kg}$ feed) was added between 2-4, 4-6 and 6-8 weeks of age to measure the effect. Control groups were fed only with commercial quail growing feed with no PTU. During the trial, the animals were weighed on a weekly basis with a $1 \mathrm{~g}$ sensitive scale, both individually and group averages were taken. Deaths were recorded daily. Special jar type water bottles and plastic feeders were used in the floor type pens. Wood shave was used as litter material. Birds were allowed to the feeds and water ad libitum during the treatment. At 60 days of age, accepted maturation in general, 10 birds from each group were sacrificed and testicular characteristics were examined (testis weights, wide and narrow diameters of testis). Wide and narrow of testes were measured by caliper. After incubation all non-hatched eggs were broken then if no embryo was observed, the egg was accepted as not fertilized. Fertility rate was calculated as follow:

$\%$ fertility = number of fertile eggs/number of total eggs set in incubation.

The obtained data set were analyzed in SAS (1998) statistical package program. Pdiff command was used to compare mean of treatment differences.

\section{RESULTS}

\section{Live weight and carcass weight}

Live weight and carcass weight means of treatment and control groups is given in Table 1 .

Depending on the time, Table 1 shows how PTU treatment affects the live weights of quails by week. The live weights of the control and treatment groups were similar at 2 weeks, differentiated from the 4th week of age, and differences between the 6 th, 7th and 8th weeks were statistically significant. At the fourth week, the highest live weight average was obtained (95.0 g) between 2-8 weeks with 0.1\% PTU added. At the sixth week, the highest live weight averages were observed in groups that were $0.5 \%$ PTU between 2-4 weeks, 0.1\% PTU between 2-4 weeks and 0.1\% PTU between 2-8 weeks. At week 7, the differences between the groups were found to be significant

Table 1 - Effects of PTU on live weight $(\mathrm{g})$ and carcass weight $(\mathrm{g})$ in quails.

\begin{tabular}{|c|c|c|c|c|c|c|c|c|}
\hline \multirow{3}{*}{ Wk. } & \multicolumn{4}{|c|}{$0.1 \%$ PTU } & \multicolumn{3}{|c|}{$0.5 \%$ PTU } & \multirow{3}{*}{ Control } \\
\hline & \multicolumn{4}{|c|}{ Process time } & \multicolumn{3}{|c|}{ Process time } & \\
\hline & $2-4 w k$ & $4-6 w k$ & $6-8 w k$ & $2-8 w k$ & $2-4 w k$ & $4-6 w k$ & $6-8 w k$ & \\
\hline 2 & $32.3 \pm 0.6^{\mathrm{ab}}$ & $33.2 \pm 0.6^{b}$ & $32.4 \pm 0.5^{a b}$ & $32.8 \pm 0.3^{b}$ & $33.3 \pm 0.5^{b}$ & $32.0 \pm 0.4^{a}$ & $31.9 \pm 0.5^{a}$ & $31.4 \pm 0.6^{a}$ \\
\hline 4 & $83.2 \pm 1.4^{a}$ & $73.8 \pm 1.2^{\mathrm{a}}$ & $75.8 \pm 1.1^{a}$ & $95.0 \pm 0.7 c$ & $94.1 \pm 1.5^{b}$ & $77.4 \pm 1.0^{a}$ & $71.2 \pm 1.5^{a}$ & $74.7 \pm 1.3^{a}$ \\
\hline 6 & $130.7 \pm 1.6^{c}$ & $126.2 \pm 1.5^{a}$ & $124.2 \pm 1.5^{\mathrm{ac}}$ & $130.1 \pm 1.1^{c}$ & $132.6 \pm 1.4^{c}$ & $130.1 \pm 1.6^{b}$ & $123.7 \pm 2.1^{\mathrm{a}}$ & $124.6 \pm 1.9^{a}$ \\
\hline 7 & $150.3 \pm 2.1^{\mathrm{cd}}$ & $144.4 \pm 1.7^{c}$ & $129.8 \pm 1.8^{a}$ & $135.4 \pm 1.0^{a}$ & $162.4 \pm 1.4^{d}$ & $154.7 \pm 1.4^{d}$ & $137.7 \pm 2.0^{b}$ & $145.2 \pm 2.2^{c}$ \\
\hline 8 & $172.8 \pm 1.6^{e}$ & $164.9 \pm 1.4^{c}$ & $157.5 \pm 1.5^{c}$ & $159.5 \pm 1.0^{c}$ & $167.4 \pm 1.2^{d}$ & $165.6 \pm 1.3^{d}$ & $149.4 \pm 1.6^{b}$ & $147.0 \pm 1.8^{a}$ \\
\hline Carcass weight & $122.0 \pm 0.7^{e}$ & $109.8 \pm 0.7^{c d}$ & $101.7 \pm 0.3^{b}$ & $94.6 \pm 0.1^{a}$ & $113.2 \pm 0.1 b^{d}$ & $103.1 \pm 0.1^{c}$ & $99.5 \pm 0.1^{b}$ & $103.87 \pm 0.1 c$ \\
\hline
\end{tabular}

\footnotetext{
$a, b, c, d, e$ : Differences between means indicated by different letters in the same row are important. $p<0.05$.
} 
and the highest live weights were determined in groups supplemented with $0.5 \%$ PTU between 2-4 and 4-6 weeks. At the eighth week, the differences between the groups were statistically significant, with the highest live weight average being obtained from the group to which $0.1 \%$ PTU was added between 2-4 weeks (172.8 g) and the lowest value was in the control group $(147.0 \mathrm{~g})$. When the average of the carcass weight of quails was examined, significant differences were found between the groups. The highest carcass weight $(122.0 \mathrm{~g})$ was obtained from the group to which $0.1 \%$ PTU was added between 2-4 weeks.

The effects of different levels of PTU on the live weights of male quails during the fattening period are shown in Table 2.

Table 2 - Effects of PTU on live weight of male quails.

\begin{tabular}{lccc}
\hline \multirow{2}{*}{ Week } & \multicolumn{3}{c}{ Live weights $(\mathrm{g})$} \\
\cline { 2 - 4 } & $0.1 \%$ PTU & $0.5 \%$ PTU & Control \\
\hline 2 & $32.7 \pm 0.1^{\mathrm{a}}$ & $33.1 \pm 0.1^{\mathrm{a}}$ & $33.1 \pm 0.1^{\mathrm{b}}$ \\
4 & $81.5 \pm 0.1^{\mathrm{a}}$ & $79.1 \pm 0.1^{\mathrm{b}}$ & $77.8 \pm 0.1^{\mathrm{b}}$ \\
6 & $125.9 \pm 0.1^{\mathrm{b}}$ & $129.7 \pm 0.1^{\mathrm{a}}$ & $126.4 \pm 0.2^{\mathrm{b}}$ \\
7 & $140.1 \pm 0.1^{\mathrm{a}}$ & $150.0 \pm 0.1^{\mathrm{b}}$ & $146.5 \pm 0.1^{\mathrm{b}}$ \\
8 & $166.9 \pm 0.1^{\mathrm{c}}$ & $156.1 \pm 0.1^{\mathrm{b}}$ & $146.9 \pm 0.1^{\mathrm{a}}$ \\
\hline
\end{tabular}

a,b,c: Differences between means indicated by different letters in the same row are important. $(p<0.05)$.

In Table 2, while there was no significant difference between the control group and PTU treatment groups at week 2 , the situation changed from the $4^{\text {th }}$ week of age and PTU effect started. At the the $4^{\text {th }}$ week, the live weight average was obtained from the $0.1 \%$ PTU group with the highest results, the lowest value was obtained from the control group. At week 6 , live weight average values were changed and the lowest value was obtained from the $0.1 \%$ PTU group. At week 7 , differences between the groups were also significant, but the lowest mean live weight was observed in the $0.1 \%$ PTU supplement group. At the $8^{\text {th }}$ week, the differences between the treatment and control groups were statistically significant $(p<0.05)$ and the lowest and the highest values were found in the control and $0.1 \%$ PTU group.

\section{Testis traits}

The testis traits of the quail, PTU added to the ration, and the effects of PTU on the fertility rate are given in Table 3.

The testis weights were significantly $(p<0.05)$ affected by the ration added PTU, and the treatment groups had a higher average than the control group. The highest values for testicular weight were obtained from the groups supplemented with 0.5\% PTU. The PTU added to the ration also had a significant effect on the testicular diameter $(p<0.05)$ and the treatment groups had higher values than the control group.

The PTU was observed to be effective in terms of the fertility rate. While the lowest value for the fertility rate was obtained from the control group $(76.7 \%)$, the highest values were observed in groups supplemented with $0.5 \%$ PTU addition (85.0\%) between 2-4 weeks, $0.1 \%$ PTU (84.3\%) between 4-6 weeks, and 0.1\% PTU at 6-8 weeks (85.1\%).

\section{DISCUSSION}

In this study, the effects of $0.1 \%$ and $0.5 \%$ PTU in quail ration at $2-4,4-6,6-8$ and $2-8$ week time intervals were investigated in terms of live weight and some reproductive characteristics after 8 weeks of growth period.

When the quail's live weight changes were examined at different periods, the effect of PTU started from the 4th week until the end of the fatting period (Table 1). In general, treatment groups had a higher live weight than the control group, because the treatment groups had statistically higher mean than the control group, indicating that PTU has a positive effect on body weight. In general, treatment groups were better than the control group (Table 2) when evaluated only for different PTU addition levels. The highest effect of the PTU has been in weeks 7 and 8 , because a very significant increase has been observed in these weeks.

In terms of carcass weight, there were significant differences between control and treatment groups, generally treatment groups (except 2 groups) had

Table 3 - Effects of PTU on testis weight, testis diameter and fertility rate in quails.

\begin{tabular}{|c|c|c|c|c|c|c|c|c|}
\hline \multirow{3}{*}{ Traits } & \multirow{3}{*}{ Control } & \multicolumn{4}{|c|}{$0.1 \%$ PTU } & \multicolumn{3}{|c|}{$0.5 \%$ PTU } \\
\hline & & \multicolumn{4}{|c|}{ Process time } & \multicolumn{3}{|c|}{ Process time } \\
\hline & & $2-4 w k$ & $4-6 w k$ & $6-8 w k$ & $2-8 w k$ & $2-4 w k$ & $4-6 w k$ & $6-8 w k$ \\
\hline Testis weight, $\mathrm{g}$ & $1.42 \pm 0.2 \mathrm{a}$ & $2.42 \pm 0.0 \mathrm{~b}$ & $2.37 \pm 0.1 b$ & $2.49 \pm 0.0 b c$ & $2.56 \pm 0.1 c$ & $2.58 \pm 0.0 \mathrm{c}$ & $2.59 \pm 0.0 c$ & $2.61 \pm 0.0 \mathrm{c}$ \\
\hline Testis diameter, $\mathrm{mm}$ & $12.7 \pm 0.6 a$ & $19.6 \pm 0.1 b c$ & $18.0 \pm 0.1 b$ & $18.2 \pm 0.2 b$ & $22.5 \pm 0.2 c$ & $19.5 \pm 0.1 b c$ & $20.0 \pm 0.4 b c$ & $19.2 \pm 0.0 b c$ \\
\hline Fertility rate, \% & $76.7 \pm 0.7 a$ & $81.0 \pm 0.8 b$ & $84.3 \pm 0.7 c$ & $85.1 \pm 0.6 c$ & $87.6 \pm 0.7 d$ & $85.0 \pm 0.7 c$ & $81.1 \pm 0.7 b$ & $80.0 \pm 0.7 b$ \\
\hline
\end{tabular}

a,b,c: Differences between means indicated by different letters in the same row are important. $(p<0.05)$. 
higher carcass weight. It can be said that the addition of the PTU has a positive effect on the carcass weight.

The role of thyroid hormones on reproductive physiology has been clearly demonstrated in many animal species. The positive effects of PTU, an antithyroid drug, on sexual maturation and reproductive performance may depend on the time and the timing of treatment. Indeed, in this study, testis weight and testis diameter of quails were significantly influenced by PTU addition in ration (Table 3). When looking at the values of the quails in the eighth week, the treatment groups in terms of characteristics in question, had higher values than the control group. Observing the highest testicular weight in groups with $0.5 \%$ PTU added, indicating an increase in PTU dose and an increase in testicle weight.

The results obtained in this study agree with the result of Kirby et al. (1992). The results obtained in the testis diameter were similar to those of the testis weight. In terms of this feature, the control group has the lowest value. The testis diameter was also increased in relation to the increase of the PTU level. Cooke et al. (1991) reported that PTU increased testis development in rats. PTU reached approximately twice the testicular volume in rats (Kirby et al., 1992). PTU was more effective on testicular weight at 8-16 weeks of age in chickens than 0-8 weeks of age (Knowlton et al., 1999). In order to minimize the possible side effects of PTU, applying a low dose $(0.1 \%)$ on turkey's diet was suggested as more appropriate (Babacanoglu \& Sogut, 2004). Again, Kirby et al. (1996) reported that more sperm production could be achieved with increasing testicular volume when PTU was given at appropriate times to the poultry. Akhlaghi and Zamiri (2007) reported that the effect of age on body weight, semen volume, sperm motility, percentage of live sperm, sperm concentration, total number of live sperm, and serum testosterone and thyroxine (T4) levels was significant $(p<0.01)$. Transient treatment of PTU had adverse effects on live body weight of white rats; while the Control groups were $443.14 \mathrm{~g}$, Hypotyroid group had $347 \mathrm{~g}$ after 6 weeks of treatment (Kandır $\&$ Keskin, 2015). This result was consistent with the findings of Kirby et al. (1996), and the fertility rate of eggs obtained from quails with PTU added to their diet was found to be higher than the control group

As a result, transient treatment of PTU had adverse effect on body weight of chicken, turkey and rats, however it was not seen in the quail because in this study a positive effect of PTU adding to the diet by transient treatment was observed on the live weight and carcass weight of quails during different growth periods. In addition, the expected positive effect of PTU in quails was also observed in testicular weight, testicular diameter and fertility rate of the eggs as reproductive traits. It can be said that the appropriate PTU level for quails is $0.1 \%$, however, other studies may also need to be undertaken to achieve a definitive result.

\section{REFERENCES}

Akhlaghi, A. and Zamiri, M. J. Effect of transient prepubertal hypothyroidism on serum testosterone level and seminal characteristics of chickens. Iranian Journal of Veterinary Research 2007;8(1):23-31

Babacanoglu E, Sogut B. Gecici süre ile 6-N-Propyl-2-Thiouracil (PTU) muamelesinin hindilerin bazı üreme özellikleri üzerine etkisi. Proceedings of the $4^{\circ}$ Ulusal Zootekni Kongresi; 2004; Isparta: Süleyman Demirel Üniversitese; 2004. p.304-308.

Bunick D, Kirby J, Hess RA, Cooke PS. Developmental of testis messenger ribonucleic acids in the rat following propylthiouracil-induced neonatal hypothyroidism. Journal of Animal Science 1984;58(5):1255-1261.

Cooke PS, Hess RA, Porcelli J, Meisami E. Increased sperm production in adult rats after transient neonatal hypothyroidism. Endocrinology $1991 ; 129(1): 237-243$

Cooke PS, Kirby JD, Porcelli J. Increased testis growth and sperm production in adult rats following transient neonatal Goitrogen treatment: Optimization of the propylthiouracil dose and effects of Methimazol. Journal of Reproduction and Fertility 1993;97:493-499

Kai O, Nagase H, Suzuki M, Kakegawa T, Sato K. Effects of hypothyroidism with treatment of an anti-thyroid drug. Propylthiouracil on immune responses in chickens. Veterinary Immunology and Immunopathology 1993;36(2):123-35.

Kandir, S. Effects of hypothyroidism and hyperthyroidism on hematological parameters in rats. Veterinary Journal of Ankara University 2016;63:371-376.

Kirby JD, Jetton AE, Cooke PS, Hess RA, Bunick D, Ackland JF, et al. Developmental hormonal profiles accompanying the neonatal hypothyroidism induced increases in adult testis size and sperm production in the rat. Endocrinology 1992;131:559-565.

Kirby JD, Mankar MV. Adult testicular enlargement in the broiler breeder male following transient prepubertal propylthiouracil (PTU) treatment. Journal of Poultry Science 1995; 74(Suppl 1):1-240

Kirby JD, Mankar MV, Hardesty D, Kreider DL. Effects of transient prepubertal 6-N-propyl-2-thiouracil treatment on testis development and functional in the domestic fowl. Biology of Reproduction 1996;55(4):910-916.

Knowlton JA, Siopes TD, Rhoads ML, Kirby JD. Effects of transient treatment with 6-N-Propyl-2-Thiouracil on testes development and function in breeder hens. Poultry Science 1999;78(7):999-1005.

Kolaja KL, Petrick JS, Klaassen CD. Inhibition of gap-junctional-intercellular comunication in thyroid-follicular cells by propylthiouracil and low iodine diet. Toxicology 2000;143(2):195-202.

Luger D, Shinder D, Yaha S. Hyper-or Hypothyroidism: It's association with the development of ascites syndrome in fast-growing chickens. General and Comperative Endocrinology 2002;127(3):293-299.

Marks HL. Fertility of chickens fed thiouracil prior to sexual maturity. Poultry Science 1969;48:1612-1618. 
Ozkan K, Bulgurlu S. Kümes hayvanlarının beslenmesi [n.264]. Bornova/ İzmir (TUR): Ege Üniversitesi Yayınları 1995;

Palmero S, Prati M, De Marco P, Fugassa E. Thyroidal regulation of nuclear tri-iodthyronine receptors in the developing rat testis. Journal of Molecular Endocrinology 1992;92(1):55-59.

Queen WH, Christensen VL, May JD. Supplemental thyroid hormones and molting in turkey breeder hens. Poultry Science 1997;76(6):887-893.

SAS. Guide for personal computers. 6th ed. Cary: SAS Institute; 1998.

Schmiedeberg SV, Hanten U, Goebel C, Schuppe HC, Uetrecht J, Gleichman ET. Cells ignore the parent drug propylthiouracil but are sensitized to a reactive metabolite generated in vivo. Clinical Immunology and Immunopathology 1996;80(2):162-167.

Tsukada A, Ohkubo T, Sakaguchi K, Tanak M, Nakashima K, Hayashida $\mathrm{K}$, et al. Thyroid hormone are involved in insulin-like growth factor (IGF)-I production by regulating growth hormone receptor (GHR) in the chicken. Proceedings of the 6th International Symposium on Avian Endocrinology; 1996; Alberta, Lake Louise. Canadá. p.31-1-2-3-4-5

Yılmaz B. Hormonlar ve üreme fizyolojisi. Ankara: Ankara Üniversitesi Veteriner Fakültesi. Fizyoloji Anabilim Dalı; 1999 
